удК 342.7

DOI https://doi.org/10.32837/pyuv.v0i2(31).557

\author{
А.Ю.Олійник \\ orcid.org/0000-0002-6245-4804 \\ кандидат юридичних наук, професор, \\ професор кафедри приватного та публічного права \\ факультету підприємництва та права \\ Київського наиіонального університету технологій та дизайну
}

\title{
РЕАЛІЗАЦІЯ КОНСТИТУЦІЙНОЇ СВОБОДИ ОСОБИ НА ВИРОБНИЧУ ПІДПРИЕМНИЦЬКУ ДІЯЛЬНІСТЬ
}

Постановка проблеми та їі зв'язок із важливими практичними завданнями. Під свободою підприємницької діяльності розуміють торговельну, комерційну діяльність, діяльність із купівлі-продажу товарів тощо. Таке уявлення є неповним. У теорії розрізняють три основні види підприємницької діяльності: виробничу, фінансово-кредитну, комерційну. Практична реалізація конституційної свободи особи на підприємницьку діяльність у процесі виробництва продукції $\mathrm{e}$ провідним видом підприємницької діяльності, спрямованим на виробництво продукції, надання послуг, виконання робіт для споживачів тощо. Зрозумілим стає зв'язок свободи особи на підприємницьку діяльність із важливими практичними завданнями господарювання.

Аналіз останніх досліджень і публікацій свідчить, що вивчення конституційних прав i свобод особи в Україні (включаючи і конституційну свободу на підприємницьку діяльність) здійснювалося у процесі підготовки дисертацій, монографій, підручників і посібників, статей та інших наукових праць. Серед дослідників: О.В. Бігняк, А.С. Васильєв, В.М. Гайворонський, В.П. Жусман, А.Ю. Олійник, В.Ф. Погорілко, П.М. Рабінович, О.Ф. Скакун, Н.І. Склярук, В.Л. Федоренко та ін.

Метою дослідження $\epsilon$ аналіз реалізації конституційної свободи особи на підприємницьку діяльність у процесі виробництва продукції. Відповідно до визначеної мети завданнями роботи $€:$ а) аналіз наукових праць щодо реалізації названої свободи особи на підприємницьку діяльність; б) формулювання визначення реалізації конституційної свободи особи на виробничу підприємницьку діяльність і її видів; в) пропозиція висновків і рекомендацій.

Виклад основного матеріалу. Для підприємництва як методу господарювання характерні такі основні ознаки: самостійність і незалежність суб'єктів господарювання; господарський ризик; економічна відповідальність [1]. В основі реалізації конституційної свободи особи на підприємницьку діяльність слід виділяти декілька іï видів. О.В. Бігняк розглядає виробниче підприємництво, фінансово-кредитне та комерційне [2].
Виробниче підприємництво спрямоване на вироблення продукції, надання послуг та інформації, виконання робіт, представлення різноманітних послуг, створення духовних благ тощо. Виробниче підприємництво належить до найбільш складних, серйозних, суспільно необхідних і водночас важких видів бізнесу. Із цим частково пов' язаний i той факт, що до виробничого підприємництва спостерігається значно менше тяжіння, ніж до інших видів підприємницької діяльності, які значно швидше і простіше приносять прибутки. Так, із загальної кількості діючих малих підприємств лише кожне шосте функціонує у промисловості $(16,4 \%$ від загальної кількості діючих малих підприємств), кожне дванадцяте - у будівництві $(8,6 \%)$, лише $4,4 \%$ - на транспорті. Однак в оптовій і роздрібній торгівлі, включаючи торгівлю транспортними засобами та послуги з їх ремонту, діють $3 / 5$ малих підприємств $(40,6 \%)$ [3].

На нашу думку, для формулювання визначення реалізації конституційної свободи особи на виробничу підприємницьку діяльність необхідно розкрити її ознаки. Ознаками реалізації конституційної свободи особи на виробничу підприємницьку діяльність $є: 1)$ втілення конституційних норм в реальні суспільні відносини; 2) названі норми регулюють свободи особи на виробничу підприємницьку діяльність, що спрямована на: a) вироблення продукції; б) надання послуг та інформації; в) виконання робіт; г) здійснення різноманітних послуг; д) створення духовних благ; 3) метою діяльності є отримання: а) прибутку; б) соціального результату.

Однією з ознак є втілення конституційних норм у реальні суспільні відносини щодо свободи особи на виробничу підприємницьку діяльність, що слід розглядати як їх реалізацію. О.Ф. Скакун визначає реалізацію норм права як втілення ix у правомірній поведінці суб'єктів права, у їх практичній діяльності. Вона розглядає форми i способи безпосередньої реалізації норм права. Серед форм О.Ф. Скакун виділяє просту і складну. Проста (безпосередня) форма реалізації відбувається без участі держави способами додержання, виконання, використання норм права. Складна (опосередкована) форма реалізації відбувається за 
участю держави способом застосування норм права [4, с. 418-419]. Конституційна свобода підприємців на виробничу підприємницьку діяльність полягає в тому, що вони без обмежень самостійно здійснюють будь-яку підприємницьку діяльність, не заборонену законом, тобто реалізують конституційну норму у простій формі способом використання. При здійснення окремих видів підприємництва вони додержуються правових норм, встановлених законодавчими актами. Так, у ст. 4 Закону Української РСР «Про підприємництво» закріплюються обмеження у здійсненні підприємницької діяльності, а саме: 1) діяльність, пов'язана 3 обігом наркотичних засобів, психотропних речовин, їх аналогів і прекурсорів; 2) діяльність, пов'язана з охороною окремих особливо важливих об'єктів права державної власності; 3) діяльність, пов'язана з виробництвом бензинів моторних сумішевих або з додаванням (змішуванням) біоетанолу та/або біокомпонентів на його основі до вуглеводневої основи (бензинів, фракцій, компонентів тощо); 4) діяльність, пов'язана з виробництвом біоетанолу, здійснюється суб'єктами господарювання за наявності відповідної ліцензії [5]. Законами України, також, визначаються правові та організаційні засади: а) функціонування дозвільної системи у сфері господарської діяльності; б) порядку діяльності дозвільних органів, уповноважених видавати документи дозвільного характеру, й адміністраторів [6]; в) реалізації державної регуляторної політики у сфері господарської діяльності [7].

Отже, конституційні норми, що регулюють свободу особи на виробничу підприємницьку діяльність, можуть реалізуватися у простій і складній формах способами додержання, виконання, використання та застосування.

Названі норми регулюють свободу особи на виробничу підприємницьку діяльність, спрямовану на: а) вироблення продукції; б) надання послуг та інформації; в) виконання робіт; г) здійснення різноманітних послуг; д) створення духовних благ тощо. Як показує практика, при виборі того чи іншого виду підприємницької діяльності слід враховувати такі критерії (фактори), зокрема: а) вид товару, який пропонується на ринок, його якість, асортимент; б) споживчий попит на товар або послугу; в) фінансові можливості підприємця, наявність матеріальних, трудових ресурсів; г) економічний стан у цій сфері бізнесу, рівень розвитку конкуренції; г) досвід роботи підприємця, його кваліфікацію; д) перспективність виду підприємницької діяльності, можливості одержання достатнього прибутку тощо [8]. H.I. Склярук стверджує, що метою суспільного виробництва будь-якої держави є задоволення потреб громадян, які проживають на її території. Для досягнення цієї мети суспільство організує матеріальне виробництво [9, с. 5]. Задоволення потреб людини у товарах, послугах та інформації, виконанні робіт і створенні матеріальних і духовних благ має перспективне значення та певну складність і потребує значних зусиль і певних термінів розвитку від ідеї вироблення товарів і надання послуг до отримання ефекту у вигляді прибутку, досягнення економічних і соціальних результатів. На думку B.М. Гайворонського, підприємець визнається однією із центральних фігур господарської (підприємницької) діяльності. Його інноваційність полягає не лише у виготовленні нового продукту та впровадженні нових технологій, а і в освоєнні нових ринків збуту, нових джерел сировини, нових форм індустріальної організації тощо [10, с. 54].

Отже, на думку авторів-господарників, виробнича підприємницька діяльність не обмежується лише виробництвом продукції, а має більш широке призначення і реалізується у виробленні продукції, наданні послуг та інформації, виконанні робіт, здійсненні різноманітних послуг і створенні матеріальних і духовних благ для задоволення потреб та інтересів людини та громадянина на території будь-якої країни.

На думку багатьох авторів-господарників, виробниче підприємництво безпосередньо пов'язане з виробництвом продукції, здійсненням робіт і послуг, наданням інформації та подальшою реалізацією покупцям, споживачам результатів виробництва і розрізняється за формами та видами. Розрізняють дві форми виробничого підприємництва: традиціоналістське й інноваційне підприємництво. Традиціоналістське підприємництво орієнтоване на виробництво традиційних товарів для постачання на ринок. Асортимент таких товарів давно випускається виробником, відносно стабільний і не підлягає суттєвим змінам за різновидами [8]. Інноваційне підприємництво передбачає організацію виробництва із широким використанням нових технологій та інновацій. Результатом такої організації виступає новий (якого не існувало раніше) товар або товар із принципово новими характеристиками, властивостями або навіть сферами використання. Практика виробничої підприємницької діяльності у будь-якій формі включає в себе елементи інноваційного процесу [8]. Серед видів виробничої підприємницької діяльності розрізняють: а) основні; б) допоміжні. До основних відносять види виробничої підприємницької діяльності, результатом яких $€$ виробництво товару, готового до споживання (виробничого або індивідуального). Функція виробництва є для підприємця провідною. Допоміжними видами підприємницької активності $€$ такі, які обслуговують, супроводжують виробництво (наприклад, інноваційна, науково-технічна, інформаційна, інжинірингова, конструкторська, консультаційна, маркетингова, лізингова діяль- 
ність, виробниче споживання товарів і послуг, збут продукції тощо) [8]. Форми та види виробничої підприємницької діяльності здійснюються підприємцями за умови наявності у них конституційної свободи. Як вказується у спеціальній літературі, під підприємництвом розуміють самостійну, ініціативну, систематичну, на власний ризик, не заборонену законом господарську діяльність із виробництва продукції, виконання робіт, надання послуг із метою одержання прибутку [11, с. 133].

Отже, згадані вище форми та види діяльності можуть бути реалізовані лише за наявності у підприємців конституційної свободи на виробничу підприємницьку діяльність. Саме наявність свободи дає можливість підприємцю діяти на власний ризик у межах чинного законодавства.

Метою виробничої підприємницької діяльності є отримання економічного чи соціального результату та прибутку. Таку позицію щодо підприємницької діяльності підтримують не всі автори. Так, В.М. Гайворонський до ознак підприємницької діяльності відносить досягнення економічних і соціальних результатів із метою одержання прибутку [10, с. 52]. С.І. Іщук вважає за потрібне змінити концепцію конституційної фіксації свободи особи в економічній сфері. Виходячи із таких позицій, на його думку, варто змінити концепцію конституційної фіксації свободи особи в економічній сфері та забезпечити гарантії свободи вільної та ініціативної підприємницької діяльності у різних її проявах [11, с. 15]. Протилежною $€$ позиція В.Ф. Погорілка та В.Л. Федоренка, котрі вважають, що виробнича підприємницька діяльність передбачає за мету лише отримання прибутку [12, с. 226]. Такої ж думки дотримуються П.М. Рабінович і М.І. Хавронюк [13, с. 219].

Ми пропонуємо внести зміни до ст. $41 \mathrm{KoH}-$ ституції України і ст. 43 Господарського кодексу України. Ст. 42 ч. 1 Конституції України викласти в такій редакції: перед словами «кожен має право на підприємницьку діяльність» вставити «економічна свобода підприємництва в Україні гарантується» і далі по тексту. Ст. 43 ГК України сформулювати так: замість слів "підприємці мають право» закріпити «підприємцям гарантується економічна свобода» і далі по тексту.

Отже, на нашу думку, автори В.М. Гайворонський і C.I. Іщук мають більш перспективну думку щодо свободи виробничого підприємництва та справедливо виступають за розширення мети підприємницької діяльності свободи особи щодо досягнення економічних і соціальних результатів та одержання прибутку.

Висновки. Підсумовуючи сказане, зробимо деякі висновки. Ознаками реалізації конституційної свободи особи на виробничу підприємницьку діяльність $є: 1)$ втілення конституційних норм у реальні суспільні відносини; 2) названі норми регулю- ють свободи особи на виробничу підприємницьку діяльність, спрямовану на: а) вироблення продукції; б) надання послуг та інформації; в) виконання робіт; г) здійснення різноманітних послуг; д) створення духовних благ; 3) метою діяльності є отримання: а) прибутку; б) соціального результату.

Реалізація конституційної свободи особи на підприємницьку діяльність у процесі виробництва продукції може розглядатися як втілення конституційних норм у реальні суспільні відносини, що регулюють свободу особи на виробничу підприємницьку діяльність при виробленні продукції, наданні послуг та інформації, виконанні робіт і створенні матеріальних і духовних благ із метою отримання прибутку і (чи) соціального результату.

Пропонуємо внести такі зміни до законодавства: а) у ст. 42 ч. 1 Конституції України перед словами «кожен має право на підприємницьку діяльність» вставити «економічна свобода підприємництва в Україні гарантується» і далі по тексту; б) у ст. 43 ГК України замість слів «підприємці мають право» закріпити "підприємцям гарантується економічна свобода» і далі по тексту. Дотримання запропонованих рекомендацій сприятиме удосконаленню реалізації конституційної свободи фізичної особи на виробничу підприємницьку діяльність.

\section{Jimepamypa}

1. Підприємництво і підприємство. URL: https:// studopedia.su/4_49228_tema--pidpriiemnitstvo-ipidpriiemstvo.html.

2. Бігняк О. Поняття права на підприємницьку діяльність. Підприємниитво, господарство і право. 2006. № 2. С. 99-102.

3. Види підприємницької діяльності. URL: https://www.sites.google.com/site/ecolicej/navcalnijproces/uroki-ekonomiki/11-a-klas/viznacalnirisi-ta-osoblivosti-pidpriemnickoie-dialnosti/vidipidpriemnickoie-dialnosti.

4. Скакун О.Ф. Теорія права і держави : підручник. Кииів : Алерта, 2012.524 с.

5. Про підприємництво : Закон Української РСР від 07 лютого 1991 р. Відомості Верховної Ради Української РСР. 1991. № 14. Ст. 168.

6 . Про дозвільну систему у сфері господарської діяльності : Закон України від 6 вересня 2005 р. Відомості Верховної Ради України. 2005. № 48. Ст. 483.

7. Про засади державної регуляторної політики у сфері господарської діяльності : Закон України від 11 вересня 2003 р. Відомості Верховної Ради України. 2004. № 9. Ст. 79.

8. Виробнича підприємницька діяльність. URL: https://msd.in.ua/virobnicha-pidpriyemnickadiyalnist/.

9. Склярук Н.I. Конспект лекцій з дисципліни «Економіка підприємства» (для студентів 3 курсу заочної форми навчання галузі знань 0305 «Економіка та підприємництво» напряму підготовки 6.030509 - «Облік і аудит») / Харк. нац. акад. міськ. госп-ва. Харків : ХНАМГ. $2012.165 \mathrm{c}$.

10. Господарське право України : підручник / В.М. Гайворонський, В.П. Жушман, Н.В. Погорецька 
та ін. ; за ред. В.М. Гайворонського та В.П. Жушмана. Харків : Право, 2005. 384 с.

11. Олійник А.Ю. Конституційні свободи людини і громадянина та їх забезпечення в Україні : монографія. Київ : КНУТД; Дніпро : ДДУВС, 2018. 371 с.

12. Іщук C.I. Окремі конституційно-правові засади функціонування громадянського суспільства в Україні : свобода підприємницької діяльності. Journal «ScienceRise: Juridical Science». 2018. № 1 (3). C. 11-17.

13. Погорілко В.Ф., Федоренко В.Л. Конституційне право України : підручник / за заг. ред. В.Л. Федоренка. Київ : КНТ, Видавництво Ліра-К, 2011. 532 с.

14. Рабінович П.М., Хавронюк М.І. Права людини і громадянина : навчальний посібник. Київ : Атіка, 2004. 464 c.

\section{Анотація}

Олійник А. Ю. Реалізація конституційної свободи особи на виробничу підприємницьку діяльність. Стаття.

У статті розглянуто поняття реалізації конституційної свободи особи на виробничу підприємницьку діяльність. Проаналізовано праці таких вчених, як В.М. Гайворонський, В.Ф. Погорілко, П.М. Рабінович, О.Ф. Скакун, В.Л. Федоренко та ін. Сформульовані та розглянуті ознаки реалізації конституційної свободи особи на виробничу підприємницьку діяльність.

Конституційні норми, що регулюють свободу особи на виробничу підприємницьку діяльність, можуть реалізуватися у простій i складній формах способами додержання, виконання, використання та застосування. Виробнича підприємницька діяльність не обмежується лише виробництвом продукції, а має більш широке призначення і реалізується виробленням продукції, наданням послуг та інформації, виконанням робіт, здійсненням різноманітних послуг і створенням матеріальних і духовних благ для задоволення потреб і інтересів людини та громадянина. Розрізняють дві форми виробничого підприємництва: традиціоналістське та інноваційне й основні та допоміжні види.

Реалізації конституційної свободи особи на підприємницьку діяльність у процесі виробництва продукціі може розглядатися як втілення конституційних норм у реальні суспільні відносини, що регулюють свободу особи на виробничу підприємницьку діяльність при виробленні продукції, наданні послуг та інформації, виконанні робіт і створенні матеріальних і духовних благ із метою отримання прибутку і (чи) соціального результату. Запропоновано зміни до законодавства, a саме: а) у ст. 42 ч. 1 Конституції України перед словами «кожен має право на підприємницьку діяльність» вставити «економічна свобода підприємництва в Укра- їні гарантується» і далі по тексту; б) у ст. 43 ГК України замість слів «підприємці мають право» закріпити «підприємцям гарантується економічна свобода» і далі по тексту.

Ключові слова: виробнича підприємницька діяльність, ознаки реалізації конституційної свободи, втілення конституційних норм у реальні суспільні відносини.

\section{Summary}

Oliynyk $A . Y u$. Realization of the constitutional freedom of a person for productive entrepreneurial activity. - Article.

The article considers the concept of realization of the constitutional freedom of a person for productive entrepreneurial activity. The works of such scientists as: V.M. Gaivoronsky, V.F. Pogorilko, P.M. Rabinovich, O.F. Skakun, V.L. Fedorenko and others. The signs of realization of the constitutional freedom of a person for productive entrepreneurial activity are formulated and considered.

Constitutional norms governing the freedom of a person to engage in productive entrepreneurial activity can be implemented in simple and complex forms by means of observance, implementation, use and application. Industrial entrepreneurial activity is not limited to production, but has a broader purpose and is realized by production, provision of services and information, performance of works, implementation of various services and creation of material and spiritual goods to meet the needs and interests of man and citizen. There are two forms of industrial entrepreneurship: traditionalist and innovative and basic and auxiliary types.

Realization of the constitutional freedom of a person to entrepreneurial activity in the process of production can be considered as the embodiment of constitutional norms in real social relations governing the freedom of a person to productive entrepreneurial activity in production, provision of services and information, performance of works and creation of material and spiritual goods profit and (or) social result. Proposed changes to the legislation, namely: a) Art. 42 part 1 of the Constitution of Ukraine before the words "everyone has the right to entrepreneurial activity" insert "economic freedom of entrepreneurship in Ukraine is guaranteed" and further in the text; b) Art. 43 of the Civil Code of Ukraine instead of the words "entrepreneurs have the right" to enshrine "entrepreneurs are guaranteed economic freedom" and further in the text.

Key words: productive entrepreneurial activity, signs of realization of constitutional freedom, embodiment of constitutional norms in real social relations. 